\title{
Acquired lipoprotein lipase deficiency associated with chronic urticaria. A new etiology for type I hyperlipoproteinemia
}

\author{
Angel L García-Otín ${ }^{1}$, Fernando Civeira ${ }^{1}$, Julia Peinado-Onsurbe ${ }^{2}$, Carmen Gonzalvo ${ }^{1}$, Miguel Llobera ${ }^{2}$ and \\ Miguel Pocovi ${ }^{1}$ \\ ${ }^{1}$ Departments of Biochemistry. Molecular Biology and Medicine, University of Zaragoza, Hospital Miguel Servet, Av. Isabel La Católica 1-3, 50009, \\ Zaragoza, Spain and ${ }^{2}$ Department of Biochemistry and Molecular Biology, University of Barcelona, Av. Diagonal 645, O8028, Barcelona, Spain \\ (Correspondence should be addressed to F Civeira, Servicio de Medicina Interna, Hospital Miguel Servet, Av. Isabel La Católica 1-3, 50009, Zaragoza, \\ Spain; Email: civeira@posta.unizar.es)
}

\begin{abstract}
Type I hyperlipoproteinemia (type I HLP) is a rare disorder of lipid metabolism characterized by fasting chylomicronemia and reduced postheparin plasma lipoprotein lipase (LPL) activity. Most cases of type I HLP are due to genetic defects in the LPL gene or in its activator, the apolipoprotein CII gene. Several cases of acquired type I HLP have also been described in the course of autoimmune diseases due to the presence of circulating inhibitors of LPL. Here we report a case of type I HLP due to a transient defect of LPL activity during puberty associated with chronic idiopathic urticaria (CIU). The absence of any circulating LPL inhibitor in plasma during the disease was demonstrated. The LPL genotype showed that the patient was heterozygous for the D9N variant. This mutation, previously described, can explain only minor defects in the LPL activity. The presence of HLP just after the onset of CIU, and the elevation of the LPL activity with remission of the HLP when the patient recovered from CIU, indicate that type I HLP was caused by CIU. In summary, we report a new etiology for type I HLP - a transient decrease in LPL activity associated with CIU and with absence of circulating inhibitors. This is the first description of this association, which suggests a new mechanism for type I HLP.
\end{abstract}

European Journal of Endocrinology 141 502-505

\section{Introduction}

Lipoprotein lipase (LPL) is the major enzyme responsible for the hydrolysis of triglycerides transported by chylomicrons and very low density lipoproteins (VLDL). LPL is present as an active dimer which is noncovalently linked to proteoglycans in the endothelial wall, where it can be transferred to chylomicrons and VLDL. Apolipoprotein (apo) CII, carried by the target lipoproteins for LPL, is the physiological activator of LPL in plasma.

Type I hyperlipoproteinemia (type I HLP) is a rare disorder of lipid metabolism characterized by fasting chylomicronemia, with subsequent hypertriglyceridemia, and reduced postheparin plasma LPL activity. This hyperlipoproteinemia is due to a decreased hydrolysis of triglycerides transported in chylomicrons and VLDL. Type I HLP is characterized clinically by repeated episodes of abdominal pain, with or without pancreatitis, eruptive cutaneous xanthomatosis and hepatosplenomegaly. Three inherited disorders have been described to be responsible for type I HLP, two of them being autosomal recessives (familial LPL deficiency and familial apo CII deficiency), and the third showing an autosomal dominant mode of transmission (familial inhibitor of LPL) (1).

Several cases of acquired type I HLP have also been described in the course of autoimmune diseases, such as systemic lupus erythematosus $(2,3)$, idiopathic thrombocytopenic purpura and Graves' disease (4). The mechanism in these autoimmune disorders is probably related to the presence in plasma of a circulating autoantibody directed against LPL, as demonstrated by Pruneta et al. (5) in a case of autoimmune type I HLP.

We report one case of acquired type I HLP in a 13year-old girl, associated with chronic idiopathic urticaria (CIU). This is, to our knowledge, the first description of this association, and the first acquired form of type I HLP not related to the presence of circulating inhibitors of LPL.

\section{Case report}

A 13-year-old girl was referred to Miguel Servet Hospital for evaluation of severe hypertriglyceridemia. No family history of hyperlipidemia, pancreatitis or coronary heart disease was present. Her aunt had 
Table 1 Lipid, apolipoprotein, lipoprotein and lipolytic activities from the patient. All concentrations pre- and post-urticaria are means of two different determinations, except for LPL and HL activities. Lipid and apolipoprotein concentrations during urticaria phase are means ${ }^{\#}$ of at least 6 different determinations, except for LPL and HL activities (each from one determination).

\begin{tabular}{|c|c|c|c|c|c|c|c|c|}
\hline & $\begin{array}{l}\text { Total cholesterol } \\
\text { (mg/dl) }\end{array}$ & $\begin{array}{l}\text { Triglycerides } \\
\text { (mg/dl) }\end{array}$ & $\begin{array}{l}\text { HDL-C } \\
(\mathrm{mg} / \mathrm{dl})\end{array}$ & $\begin{array}{l}\text { Apo Al } \\
(\mathrm{mg} / \mathrm{dl})\end{array}$ & $\begin{array}{l}\text { Apo B } \\
\text { (mg/dl) }\end{array}$ & $\begin{array}{c}\text { Chylomicrons } \\
(\%) \#\end{array}$ & $\begin{array}{c}\text { LPL } \\
(\mathrm{mU} / \mathrm{ml})\end{array}$ & $\begin{array}{c}\text { HL } \\
(\mathrm{mU} / \mathrm{ml})\end{array}$ \\
\hline Pre-urticaria & 191 & 56 & nd & nd & nd & nd & nd & nd \\
\hline During urticaria & 193 & 1352 & 15 & 86 & 65 & 64 & 8 & 78 \\
\hline Post-urticaria & 168 & 58 & 40 & 115 & 57 & 0 & 21 & 82 \\
\hline Controls $(n=2)$ & 196 & 98 & 48 & 138 & 77 & 0 & 47 & 109 \\
\hline
\end{tabular}

HDL-C, high density lipoprotein cholesterol; nd, not determined.

\# Percentage of total lipoproteins contained in chylomicron subfraction observed by cellulose acetate gel electrophoresis.

systemic lupus erythematosus and she was also normolipidemic.

Previous lipid analysis at 7 and 10 years of age were normal (Table 1). At the age of 11 , three months before menarche, generalized skin lesions consisting of itchy edematous papules and wheals, frequently associated with angioedema, occurred. Skin lesions appeared in crises and after a few months urticaria episodes presented almost daily in spite of histamine antagonist treatment. After the appropriate diagnostic testing, she was diagnosed as having CIU. Four months after the onset of CIU, a blood test revealed the presence of severe hypertriglyceridemia (triglyceride concentration $2122 \mathrm{mg} / \mathrm{dl}$ ). During the following three years her triglyceride levels remained elevated ranging from 375 to $2765 \mathrm{mg} / \mathrm{dl}$ (Table 1) in spite of various diet and drug treatments. The lowest triglyceride levels during this period were obtained after severe fat restriction $(<10 \%$ of total calories from fat) and $100 \mathrm{mg} /$ day fenofibrate. Throughout this period, she presented with several acute episodes of abdominal pain with normal amilasemia (some of them required hospitalisation) and unexplained crises of blunted vision. During this three-year period no medication other than $\mathrm{H} 1$ receptor antagonists were prescribed for her urticaria.

At the age of 15 , crises of urticaria became less frequent until they spontaneously disappeared. Her triglycerides returned to normal values (Table 1), fenofibrate treatment was stopped, and the diet was progressively less restricted in fat. After 6 months without any lipid lowering drug and with a standard free living diet (35\% calories from fat) her triglycerides were $44 \mathrm{mg} / \mathrm{dl}$. A new determination of her LPL activity showed an increase up to $21 \mathrm{mU} / \mathrm{ml}$, an increment of $260 \%$ (Table 1).

\section{Methods}

Lipid plasma concentrations in the proband, her parents, sister and maternal grandparents were obtained after at least $10 \mathrm{~h}$ fasting. Measurements of total plasma cholesterol and triglycerides were determined by enzymatic methods, high density lipoprotein (HDL) cholesterol was assayed after precipitation with magnesium-phosphotungstate (Boehringer Mannheim,
Germany), and apolipoprotein AI and B concentrations were quantified by rate immunonephelometry (Beckman, USA). All lipid analyses were performed in a laboratory participating in a lipid standardization program. Plasma lipoproteins in the proband were visualized after electrophoretic separation on cellulose acetate and Sudan black staining.

Cholesterol and triglyceride levels were, respectively, $212 \mathrm{mg} / \mathrm{dl}$ and $74 \mathrm{mg} / \mathrm{dl}$ in the father, $250 \mathrm{mg} / \mathrm{dl}$ and $120 \mathrm{mg} / \mathrm{dl}$ in the mother and $155 \mathrm{mg} / \mathrm{dl}$ and $78 \mathrm{mg} / \mathrm{dl}$ in the sister, and triglyceride levels in the grandfather and grandmother were $191 \mathrm{mg} / \mathrm{dl}$ and $120 \mathrm{mg} / \mathrm{dl}$ respectively.

Fasting plasma LPL and hepatic lipase (HL) activities were measured in the proband and in normolipidemic controls before and $15 \mathrm{~min}$ after the intravenous injection of 100 units heparin $/ \mathrm{kg}$ body weight. Samples were chilled to $4^{\circ} \mathrm{C}$, immediately centrifuged, aliquoted and stored at $-80^{\circ} \mathrm{C}$ until analysis. LPL and HL activities were measured by the methods described by Ramirez et al. (6) and Ehnholm and Kuuisi (7) respectively. Plasma LPL activity in the proband was only $18 \%$ of control values. To avoid a possible interference in the LPL activity in the proband due to an excess of lipids, her plasma samples were also studied after ultracentrifugation $\left(70000\right.$ r.p.m. $/ 4^{\circ} \mathrm{C} /$ $24 \mathrm{~h}$ ) and also after delipidation with cold acetone. No differences were obtained in her LPL activity after these procedures. LPL and HL activities in the proband and normolipidemic controls are shown in Table 1.

The ability of the proband's apo CII to activate LPL was studied by comparing it with control plasma. Fifteen microliters of pre- and postheparin plasma samples from a control subject were incubated with substrate in the presence of inactivated rat serum (as a source of apo CII) or in the presence of the patient's plasma. The incubations were carried out at $25^{\circ} \mathrm{C}$ for $30 \mathrm{~min}$. The addition of the patient's plasma induced the same LPL activity as the control serum, indicating that the LPL activating activity was normal. In order to investigate the presence of a circulating inhibitor of LPL activity in the proband's plasma, $15 \mu \mathrm{l}$ from a control plasma were incubated for $30 \mathrm{~min}$ with the same amount of the proband's plasma. LPL activity in the proband was previously inactivated at $65^{\circ} \mathrm{C}$ for $30 \mathrm{~min}$. 
Postheparin LPL activity was then measured as described above. The LPL activity showed similar values, indicating the absence of any LPL inhibitor in the proband's plasma.

The apo E genotype was determined as previously described (8) for the proband, her parents and for the normolipidemic controls. The genotype of the proband and her mother was E3/E4, while it was E3/E3 for the other subjects in the study.

All study subjects were checked for the presence of three common variants of the LPL gene: D9N, G188E and N291S. Specific regions of the LPL gene were amplified by PCR in each case and the material obtained was digested with restriction enzymes as previously described (9-11). The proband and her mother were identified as heterozygous carriers of the D9N mutation in the LPL gene, which causes a substitution of Asn for Asp at codon 9 of LPL.

\section{Discussion}

Chylomicronemia syndrome is a relatively common lipid disorder usually associated with a quite evident metabolic abnormality, such as diabetes mellitus, or alcohol consumption, especially in the presence of a genetic form of hyperlipidemia, i.e. familial hypertriglyceridemia or familial combined hyperlipidemia. Chait and Brunzell (12) studied a group of 54 patients with plasma triglycerides over $2000 \mathrm{mg} / \mathrm{dl}$ and they found that severe hypertriglyceridemia is often due to the coexistence of familial and secondary forms of hyperlipidemia. In their study, only 3 patients $(5.6 \%)$ did not have any recognizable cause. Normal lipid values in the relatives of the patient can exclude both familial hypertriglyceridemia and familial combined hyperlipidemia. Secondary metabolic causes for the hyperlipidemia were excluded because of her normal plasma glucose levels and glucose tolerance test, thyrotropin and thyroid hormones, renal function, as well as the absence of alcohol consumption or any medication intake. Absence of the broad beta band in serum electrophoresis and the presence of apo E3/E4 genotype in the proband excluded type III hyperlipoproteinemia which in some cases can produce severe hypertriglyceridemia (13). The absence of compatible symptoms and a negative profile for organ-specific autoantibodies (rheumatoid factor, antiparietal cell, antithyroid peroxidase, antithyroid globulin, thyroid-stimulating antibody, anti smooth muscle cell) and organ-nonspecific autoantibodies (ANA, anti DNA, anti Sm, anti RNP, anti Ro) make the diagnosis of an autoimmune disease very unlikely.

The proband status as an LPL D9N heterozygous carrier can explain a partially diminished plasma LPL activity, as described by Mailly et al. (9), but it cannot account for the severe LPL deficiency observed in this case. The variant D9N has been associated with mild hypertriglyceridemia and it has a high prevalence in hyperlipidemic subjects.
Chylomicronemia in this case seems to be clearly associated with an acquired and transient defect in LPL plasma activity. The mechanism of this defect was not elucidated, as no plasma inhibitor could be detected in plasma, in contrast with previously described acquired defects. Since CIU and hyperlipidemia showed temporary coexistence, this probably reflects the fact that CIU triggered the hypertriglyceridemia.

Hide et al. (14) have recently identifed the presence of an immunoglobulin (Ig) G autoantibody against the alpha subunit of the high-affinity IgE receptors (IgEFceRI) that cause the release of histamine from basophil of healthy donors. Mast cells activated through their IgE-FceRI release different mediators as proteoglycans and proinflammatory cytokines that could modify the primary site of action of LPL - the luminal surface of endothelial cells where the enzyme is anchored to proteoglycans (15). The idea that CIU has an autoimmune mechanism is also supported by its association with autoimmune thyroid disease (16) and it could also be possible that the LPL deficiency in this case was due to the presence of a non-circulating autoantibody against the enzyme.

Another predisposing mechanism to chylomicronemia in this case is the temporary association of lipid and lipoprotein changes with puberty $(17,18)$. Physiological changes during puberty include an increase in plasma triglycerides, which is due to the higher levels of sexual hormones, especially estrogens. It has previously been shown that the phenotypic expression of type I hyperlipidemia is modifed by estrogens, and some patients present their first symptoms during pregnancy (19). Bucher et al. (20) have recently described the case of a girl compound heterozygote for two missense mutations in the LPL gene with a severe increase in triglyceride plasma concentration during puberty due to a marked accumulation of chylomicrons, without modifications in the VLDL, LDL and HDL values, suggesting that the catabolism of chylomicrons in type I hyperlipoproteinemia is further affected by estrogens.

In summary, we report the first description of type I HLP due to an acquired LPL deficiency during puberty associated with CIU. The absence of a circulating LPL inhibitor in plasma during the disease, and the spontaneous remission of the HLP with recovery of the LPL activity with the cure of CIU suggest a new mechanism for type I HLP.

\section{Acknowledgements}

This work was supported by the FIS project 97/001002. We thank Dr A Cenarro for helpful comments on this manuscript.

\section{References}

1 Brunzell J. Familial lipoprotein lipase deficiency and other causes of the chylomicronemia syndrome. In The Metabolic and Molecular 
Bases of Inherited Disease, edn 7, ch 59, pp 1913-1932. Eds C Scriver, A Beaudet, W Sly \& D Valle. New York: McGraw-Hill, 1995.

2 Glueck CJ, Levy RI, Glueck HI, Gralnick HR, Greten H \& Fredrickson DS. Acquired type I hyperlipoproteinemia with systemic lupus erythematosus, dysglobulinemia and heparin resistance. American Journal of Medicine 196947 318-324.

3 Paucillo P, De Simone B, Rubba P \& Mancini M. A case of association between type I hyperlipoproteinemia and systemic lupus erythematosus (SLE). Effects of steroid treatment. Journal of Endocrinology Investigation $19869517-520$.

4 Kihara S, Matsuzawa Y, Kubo M, Nozaki S, Funahashi T, Yamashita $\mathrm{S}$ et al. Autoimmune hyperchylomicronemia. New England Journal of Medicine $19893201255-1259$.

5 Pruneta V, Moulin P, Labrousse F, Bondon PJ, Ponsin G \& Berthezene F. Characterization of a new case of autoimmune type I hyperlipidemia: long-term remission under immunosuppressive therapy. Journal of Clinical Endocrinology and Metabolism 199782 791-796.

6 Ramirez I, Kryski AJ, Ben-Zeev O, Schotz MC \& Severson DL. Characterization of triacylglycerol hydrolase activities in isolated myocardial cells from rat heart. Biochemical Journal 1985232 229-236.

7 Ehnholm C \& Kuusi T. Preparation, characterization, and measurement of hepatic lipase. Methods in Enzymology 1986 $129716-738$.

8 Hixson JE \& Vernier DT. Restriction isotyping of human apolipoprotein E by gene amplification and cleavage with HhaI Journal of Lipid Research 19913 545-548.

9 Mailly F, Tugrul Y, Reymer PWA, Bruin T, Seed M, Björn F et al. A common variant in the gene for lipoprotein lipase (Asp9 $\rightarrow$ Asn) Functional implications and prevalence in normal and hyperlipidemic subjects. Arteriosclerosis Thrombosis and Vascular Biology $199515468-478$.

10 Monsalve MV, Henderson H, Roederer G, Julien P, Deeb S, Kastelein JJP et al. A missense mutation at codon 188 of the human lipoprotein lipase gene is a frequent cause of lipoprotein lipase deficiency in persons of different ancestries. Journal of Clinical Investigation 199086 728-734.

11 Reymer PWA, Gagné E, Groenemeyer BE, Zhang H, Forsyth I, Jansen $\mathrm{H}$ et al. A lipoprotein lipase mutation (Asn291Ser) is associated with reduced HDL cholesterol levels in premature atherosclerosis. Nature Genetics 199510 28-34.
12 Chait A \& Brunzell JD. Severe hypertriglyceridemia: role of familial and acquired disorders. Metabolism 198332 209-214.

13 Mahley RW \& Rall SC. Type III hyperlipoproteinemia (dysbetalipoproteinemia): the role of apolipoprotein $\mathrm{E}$ in normal and abnormal lipoprotein metabolism. In The Metabolic and Molecular Bases of Inherited Disease, edn 7, ch 61, pp 1953-1980. Eds C Scriver, A Beaudet, W Sly \& D Valle. New York: McGraw-Hill, 1995.

14 Hide M, Francis DM, Grattan CEH, Hakimi J, Kochan JP \& Greaves MW. Autoantibodies against the high affinity IgE receptor as a cause of histamine release in chronic urticaria. New England Journal of Medicine 1993328 1599-1604.

15 Rosenberg RD, Shworak NW, Liu J, Schwartz JJ \& Zhang L. Heparan sulfate proteoglycans of the cardiovascular system. Specific structures emerge but how is synthesis regulated? Journal of Clinical Investigation 1997100 S76-S75.

16 Leznoff A \& Sussman GL. Syndrome of idiopathic chronic urticaria and angioedema with thyroid autoimmunity: a study of 90 patients. Journal of Allergy and Clinical Immunology 198984 66-71.

17 Berenson GS, Srinivasan SR, Cresanta JL, Foster TA \& Webber LS. Dynamic changes of serum lipoproteins in children during adolescence and sexual maturation. American Journal of Epidemiology $1981113157-170$.

18 Christensen B, Glueck C, Kwiterovich P, Degroot I, Chase G, Heiss G et al. Plasma cholesterol and triglyceride distributions in 13665 children and adolescents: the prevalence study of the lipid research clinics program. Pediatric Research $198014194-$ 202.

19 Ma Y, Liu MS, Ginzinger D, Frohlich J, Brunzell JD \& Hayden MR. Gene-environment interaction in the conversion of a mild-tosevere phenotype in a patient homozygous for a Ser $172 \rightarrow$ Cys mutation in the lipoprotein lipase gene. Journal of Clinical Investigation 199391 1953-1958.

20 Bucher H, Rampini S, James RW, Pometta D, Funke H, Wiebusch $\mathrm{H} \&$ Assmann G. Marked changes of lipid levels during puberty in a patient with lipoprotein lipase deficiency. European Journal of Pediatry $1997156121-125$.

Received 8 February 1999

Accepted 30 June 1999 